Goldschmidt 2021 Abstract

https://doi.org/10.7185/gold2021.3620 accumulation of $\mathrm{FeOOH}-\mathrm{As}$ and instead be mobilized under periodic reducing conditions.

\section{Characterization of Dissolved and Sedimentary Organic Matter in Arsenic Contaminated Aquifer and a Potential Riverbank Natural Reactive Barrier in Bangladesh}

\author{
${ }^{1}$ The University of Texas at San Antonio \\ ${ }^{2}$ Texas A\&M University \\ ${ }^{3}$ The University of Texas at Austin \\ ${ }^{4}$ University of Texas at San Antonio \\ Presenting Author: harshad.env@gmail.com
}

HARSHAD VIJAY KULKARNI ${ }^{1}$, TOM S VARNER ${ }^{1}$, KYUNGWON KWAK ${ }^{2}$, PETER KNAPPETT ${ }^{2}$, M. BAYANI CARDENAS $^{3}$ AND SAUGATA DATTA $^{4}$

Arsenic (As) in groundwater threatens millions of lives in Bangladesh. Much of the high As groundwater discharges to rivers, but the fate of this As is unknown. Geochemical reactions driven by mixing of As and iron (Fe)-rich reducing groundwater with oxic water from tidally and seasonally fluctuating rivers like the low-gradient Meghna, affects the fate and transport of dissolved As down the Ganges-Brahmaputra-Meghna Delta (GBMD). We hypothesize that in sufficiently permeable riverbanks, river-groundwater mixing forms a natural reactive barrier (NRB) enriched in Fe-(oxy)hydroxides which serve as a source or sink for As and similar oxyanions. Further, we hypothesize that the fresh and labile organic matter in the riverbank enables switching between strongly reducing and oxidizing conditions in NRB during tidal and seasonal river fluctuations. Here, we characterize dissolved organic matter (DOM) in the pore-waters from a fine sand Meghna riverbank (a potential NRB site, $1-5 \mathrm{~m}$ depth, for a stretch of $0-83 \mathrm{~m}$ from riverbank) and from groundwater from an underlying Holocene aquifer (2-37 $\mathrm{m}$ depth, 35-230 $\mathrm{m}$ from riverbank). We incubated sediments with deionized water at ambient $\mathrm{pH}$ and temperature to understand the mobility of sedimentary organic matter (SOM) when the sediment is flushed with fresh river-water. Dissolved organic carbon (DOC), nitrogen (DON) concentrations, absorbance and fluorescence spectroscopic properties were measured in riverbank pore-water, groundwater, and waterextracts from the sediment incubations. Riverbank pore-water had 2.6 $\pm 1.3 \mathrm{mg} / \mathrm{L}$ DOC, molar C:N 0.5-1.2, and a humic:protein fluorescence of 2.5. The groundwater DOM was characterized by DOC $3 \pm 1 \mathrm{mg} / \mathrm{L}, \mathrm{C}: \mathrm{N}$ molar ratio 0.5-3.9, and humic:protein fluorescence of 6.1. Riverbank sediments contained $116 \pm 67$ $\mathrm{mg} / \mathrm{kg}$ water-leachable org. C, molar C:N 6-37, humic:protein fluorescence of 0.2 , whereas aquifer sediments contained $1,294 \pm 263 \mathrm{mg} / \mathrm{kg}$ water-leachable org. C, molar C:N 8-66, humic:protein fluorescence of 1.6. The lower observed humic:protein fluorescence in riverbank sediments suggest a fresher and microbially-labile source of organic matter compared to older and more recalcitrant mobilizable organic matter in the aquifer. These results highlight the differences between mobilizable SOM in a typical As-contaminated aquifer and a riverbank NRB, where fresh and labile SOM may preclude the 